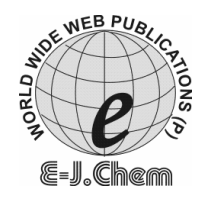

||IIIIIIIIIIIIIIIIIIIIIIIIIIIIIIII

ISSN: 0973-4945; CODEN ECJHAO

E-Journal of Chemistry

http://www.e-journals.net

2009, 6(S1), S129-S142

\title{
Removal of Cr(VI) from Aqueous Solution Using Modified Pomegranate Peel: Equilibrium and Kinetic Studies
}

\author{
TARIQ S. NAJIM ${ }^{*}$ and SUHAD A. YASSIN \\ Chemistry Dept., College of Education, Duhuk University, Iraq. \\ "Chemistry Dept., College of Science, Al-Mustansiriyah University, Iraq. \\ tariq_pru@yahoo.com
}

Received 14 March 2009; Accepted 10 May 2009

\begin{abstract}
The present investigation deals with the utilization of modified pomegrenate peel (MPGP) and formaldehyde modified pomegrenate peel (FMPGP) as adsorbents for the removal of chromium $\mathrm{Cr}(\mathrm{VI})$ from aqueous solution. A series of experiments were conducted in a batch system to evaluate the effect of system variables. The effect of $\mathrm{pH}$, initial $\mathrm{Cr}(\mathrm{VI})$ concentration, contact time, adsorbent dosage and temperature were considered. The optimal $\mathrm{pH}$ values of $\mathrm{Cr}(\mathrm{VI})$ removal by MPGP and FMPGP were 2.0 and 3.0 respectively. The time required for equilibrium was found to be about 100 minutes. The initial $\mathrm{Cr}(\mathrm{VI})$ concentration and adsorbent dosage was found to have large effect on the adsorption of $\mathrm{Cr}(\mathrm{VI})$. The maximum uptake capacities were 13.01 and $22.28 \mathrm{mg}$ of $\mathrm{Cr}(\mathrm{VI})$ per gram of MPGP and FMPGP respectively. Adsorption kinetic data were tested using pseudo-first order, pseudo-second order, Elovich and intra-particle diffusion models. Kinetic studies showed that the adsorption followed a pseudo second order reaction due to the high correlation coefficient and the agreement between the experimental and calculated values of $q_{e}$. The adsorption may follow intraparticle diffusion as well, due to the highest values of rate constants for the surface adsorption and intraparticle diffusion kinetic models, the higher values of rate constants are related to an improved bonding between $\mathrm{Cr}(\mathrm{VI})$ ions and adsorbent particle.The Dubinin-radushkevich, Freundlich and Tempkin models were the closest fit for the equilibrium data of MPGP and FMPGP.
\end{abstract}

Keywords: Adsorption, Modified Pomegranate peel, $\mathrm{Cr}(\mathrm{VI})$, kinetic, Adsorption isotherm equilibrium.

\section{Introduction}

Chromium exists in two stable oxidation states, $\mathrm{Cr}$ (III) and $\mathrm{Cr}(\mathrm{VI})$. The $\mathrm{Cr}(\mathrm{VI})$ state is of particular concern because this form is hazardous to health, due to its carcinogenic properties ${ }^{1}$. 
Chromium is introduced into the natural bodies of water from industries like electroplating, leather tanning, cement industries, steel industries, photography and inorganic chemicals production ${ }^{2}$. $\mathrm{Cr}(\mathrm{VI})$ causes skin irradiation resulting in ulcer formation. Over exposure to $\mathrm{Cr}(\mathrm{VI})$ leads to liver damage, pulmonary congestion and oedema ${ }^{3}$. In addition, hexavalent chromium is toxic and a suspected carcinogen material and it is quite soluble in the aqueous phase almost over the entire $\mathrm{pH}$ range and mobile in the natural environment ${ }^{4,5}$. Several species can be obtained from hexavalent chromium by change the concentration and $\mathrm{pH}$ of chromium solution, at $\mathrm{pH}>7$, the $\mathrm{CrO}_{4}^{-2}$ from will preferably exist in the solution, while in the $\mathrm{pH}$ between 1 and $6, \mathrm{HCrO}_{4}^{-}$is predominant. Therefore, within the normal $\mathrm{pH}$ range in natural waters, the $\mathrm{CrO}_{4}^{-2}, \mathrm{HCrO}_{4}^{-}$and $\mathrm{Cr}_{2} \mathrm{O}_{7}^{-2}$ ions are the expected forms of hexavalent chromium in the solution, which are quite soluble and mobile in water streams $s^{5,6}$. The maximum permissible levels for $\mathrm{Cr}^{+3}$ and $\mathrm{Cr}^{+6}$ ions in waste water are 5 and $0.05 \mathrm{mgL}^{-1}$, respectively. The trivalent form of chromium apparently plays an important role in plant and animal metabolism, while the hexavalent form is directly toxic to bacteria, plants and animals ${ }^{7}$. However, the most severely chromium compounds are chromium oxide and chromium sulfate as trivalent and chromium trioxide, chromic acid and dichromates as hexavalent chromium ${ }^{8}$. Established methods for the removal of chromium oxyanion from wastewater include precipitation, electrochemical reduction, ion exchange, filtration, electro deposition, membrane technology, reverse osmosis, and adsorption ${ }^{9}$. However, most of these methods have many disadvantages including incomplete metal removal, use of expensive equipment, energy requirements, and production of toxic sludge and other disposal waste products $^{10,11}$. Adsorption remains the most economical and widely used process for removal of toxic pollutants from wastewater. It is by far the most widely used process for the removal of toxic metal ions from aqueous solution. Many papers have appeared on the production of low-cost adsorbent using cheaper and readily available materials ${ }^{12-20}$.

The objective of the present study is to evaluate the capacity of modified pomegranate peel and formaldehyde modified pomegranate peel as adsorbents using the batch adsorption process. Several isotherm and kinetic models were used to evaluate the adsorbents. Condition parameters such as contact time, $\mathrm{pH}$, initial metal ion concentrations, and adsorbent concentration were considered.

\section{Experimental}

\section{Biomass}

Pomegranate peel (PGP) was collected in the northern part of Iraq was dried, then milled and sieved to particle size of $500 \mu \mathrm{m}$. The biomass was divided into two parts. The first one was shaked with distilled water for overnight then filtered, this process was repeated about ten times or until we get rid off all colored or soluble materials (it was observed that more than $40 \%$ of PGP was soluble in water) then filtered and dried in an air oven at $80{ }^{\circ} \mathrm{C}$ for overnight and named as modified pomegranate peel MPGP. The second part was reacted with $8 \%$ formaldehyde solution in a ratio of pomegranate peel to formaldehyde solution 1:5 w/v, at $60{ }^{\circ} \mathrm{C}$ for $4 \mathrm{~h}^{21 \mathrm{a}}$. The formaldehyde modified pomegranate peel FMPGP was filtered out, washed with deionized water to remove free formaldehyde, and then activated at $80^{\circ} \mathrm{C}$ for 24 $\mathrm{h}$ in an air oven. The two parts were sieved again to $150 \mu \mathrm{m}$ particle size.

Preparation of chromium solution and analysis

A stock solution of $\mathrm{Cr}(\mathrm{VI})(500 \mathrm{mg} / \mathrm{L})$ was obtained by dissolving $1.4144 \mathrm{~g}$ of $\mathrm{K}_{2} \mathrm{Cr}_{2} \mathrm{O}_{7}$ in $1 \mathrm{~L}$ of deionized water, and the solution was used for further experimental solution preparation. The $\mathrm{pH}$ values were adjusted with $0.13 \mathrm{M} \mathrm{HNO}_{3}$ or $0.1 \mathrm{M} \mathrm{NaOH}$. Analytical grade reagents were used throughout this study. $\mathrm{The} \mathrm{Cr}(\mathrm{VI})$ content in the sorption solutions was determined by atomic absorption spectrophotometer type (Analyst 200 Perkin Elmer). 


\section{Batch biosorption studies}

\section{Effect of $p H$}

The initial $\mathrm{pH}$ values were adjusted to $1.0,2.0,3.0,4.0,5.0$ and 6.0 with $0.13 \mathrm{M} \mathrm{HNO}_{3}$ and $0.1 \mathrm{M} \mathrm{NaOH}$. The effect of initial $\mathrm{pH}$ on the chromium ions adsorption onto modified pomegranate peel MPGP and FMPGP were determined using $0.1 \mathrm{~g}$ of adsorbent in $50 \mathrm{~mL}$ of $\mathrm{Cr}(\mathrm{VI})$ solution of $10 \mathrm{mg} / \mathrm{L}$ at $20{ }^{\circ} \mathrm{C}$ for 90 minutes and $140 \mathrm{rpm}$ agitation speed in case of MPGP, at $19{ }^{\circ} \mathrm{C}$ for 50 minutes using an agitation speed $240 \mathrm{rpm}$ for FMPGP.

\section{Kinetic studies}

Kinetic studies were carried out at solution $\mathrm{pH} 2.0$ for MPGP and $\mathrm{pH} 3$ for FMPGP by mixing $0.1 \mathrm{~g}$ of biomass in $50 \mathrm{~mL}$ of $\mathrm{Cr}(\mathrm{VI})$ solution $10 \mathrm{mg} / \mathrm{L}$ and agitated at $20{ }^{\circ} \mathrm{C}$ for MPGP and $16{ }^{0} \mathrm{C}$ for FMPGP and samples were collected from duplicate flasks at different time intervals, filtered by whatman filter paper no. 40 , the filterate was analyzed for residual chromium concentration.

\section{Effect of biomass dose}

The effect of sorbent dose on the removal of Cr(VI) was studied using MPGP concentration of 1,2,4 and $6 \mathrm{~g} / \mathrm{L}$ and FMPGP conc. of 1,2,4,8,12 g/L, shaked with $\mathrm{Cr}(\mathrm{VI})$ solution of $10 \mathrm{mg} / \mathrm{L}$ for 100 minutes for MPGP and 10 and $40 \mathrm{mg} / \mathrm{L}$ for $50 \mathrm{~min}$. for FMPGP and was determined from the amount of $\mathrm{Cr}$ adsorbed.

\section{Adsorption isotherm}

Adsorption isotherm experiments were carried out at different temperature $\left(20,30,40,50{ }^{\circ} \mathrm{C}\right)$ by shaking the biomass $0.1 \mathrm{~g}$ with $50 \mathrm{~mL}$ of $\mathrm{Cr}(\mathrm{VI}) 10,20,30,40 \mathrm{mg} / \mathrm{L}$ solution for $100 \mathrm{~min}$. at $\mathrm{pH} 2$ in case of MPGP and at $\mathrm{pH} 3$ in case of FMPGP. The amount of $\mathrm{Cr}(\mathrm{VI})$ adsorbed onto biomass, $\mathrm{q}_{\mathrm{e}} \mathrm{mg} / \mathrm{g}$, was calculated using the following equation:

$$
q_{e}=\frac{\left(C_{i}-C_{e}\right) \times V}{M}
$$

where, $\mathrm{C}_{\mathrm{i}}$ and $\mathrm{C}_{\mathrm{e}}$ are the initial and equilibrium liquid-phase concentration $(\mathrm{mg} / \mathrm{L})$ of $\mathrm{Cr}(\mathrm{VI})$, respectively, $\mathrm{V}$ is the volume of the solution ( $\mathrm{L}$ ) and $\mathrm{M}$ is the weight of the adsorbent used The $\mathrm{Cr}(\mathrm{VI})$ percent removal $\mathrm{R} \%$ was calculated using the following equation:

$$
R \%=\frac{\left(C_{i}-C_{e}\right)}{C_{i}} \times 100
$$

\section{Results and Discussion}

\section{Effect of $p H$ on $\mathrm{Cr}(\mathrm{VI})$ adsorption}

The $\mathrm{pH}$ value of the solution is an important factor that controls the sorption process. Figure 1 show the extent of removal of $\mathrm{Cr}(\mathrm{VI})$ as a function of $\mathrm{pH}$ for initial concentration of $10 \mathrm{mg} / \mathrm{L}$ using MPGP and FMPGP as adsorbents. It can be seen that the adsorption capacity, $\mathrm{q}_{\mathrm{e}}$ was maximum at $\mathrm{pH} 2$ and 3 for MPGP and FMPGP respectively. The predominate species ${ }^{3,21 \mathrm{~b}, 22}$ of chromium at acidic $\mathrm{pH}$ are $\mathrm{Cr}_{2} \mathrm{O}_{7}^{-2}, \mathrm{HCrO}_{4}^{-}, \mathrm{Cr}_{3} \mathrm{O}_{10}{ }^{-2}$, and $\mathrm{Cr}_{4} \mathrm{O}_{13}{ }^{-2}$. The surface of the MPGP and FMPGP become highly protonated under acidic conditions that favoured the adsorption of $\mathrm{Cr}(\mathrm{VI})$ in the anionic form. The increase in $\mathrm{pH}$ value caused a decrease in protonation of the surface, which led to a decrease in the net positive surface potential of sorbent. This decreased the electrostatic forces between sorbent and sorbate, leading to reduced sorption capacity ${ }^{23}$. Moreover, as the $\mathrm{pH}$ value increased, there was competition between $\mathrm{OH}^{-}$and chromate ions, $\mathrm{CrO}_{4}^{-2}$, which predominate in the basic solution. 




Figure 1. Effect of PH on the adsorption of $\mathrm{Cr}(\mathrm{VI}), 10 \mathrm{mg} / \mathrm{L}$, onto MPGP and FMPGP, $0.1 \mathrm{~g} / 50 \mathrm{~mL}$. Effect of contact time and initial Cr(VI) concentration

The initial concentration of metal provides an important driving force to overcome all mass transfer resistance of metal ion between the aqueous and solid phases. Hence, a higher initial concentration of $\mathrm{Cr}(\mathrm{VI})$ will increase the biosorption rate as shown in Figure 2. The influence of contact time on the amounts of $\mathrm{Cr}(\mathrm{VI})$ adsorbed at equilibrium $\mathrm{q}_{\mathrm{e}}$ is shown in Figure 3, it is clear that the rate of adsorption is so rapid at the beginning of the reaction, about $51 \%$ of $\mathrm{Cr}(\mathrm{VI})$ was removed from solution at the first five minutes, and thereafter the rate of adsorption of $\mathrm{Cr}(\mathrm{VI})$ onto MPGP and FMPGP were found to be slow, which may be attributed to the electrostatic hindrance or repulsion between the adsorbed negatively charged $\mathrm{Cr}(\mathrm{VI})$ onto the surface of MGPG or FMPGP and the available anionic $\mathrm{Cr}(\mathrm{VI})$ in solution as well as the slow pore diffusion of the $\mathrm{Cr}(\mathrm{VI})$ ion into the bulk of adsorbent ${ }^{16}$.



Figure 2. Relation between amount of $\mathrm{Cr}(\mathrm{VI})$ adsorb at equilibrium, qe, and Its initial conc. using MPGP, $0.1 \mathrm{~g} / 50 \mathrm{~mL}$, at $\mathrm{pH}$ 2, time $80 \mathrm{~min}$., and FMPGP, $0.1 \mathrm{~g} / 50 \mathrm{~mL}$, at $\mathrm{pH} 3$, time 100 min. temperature $30{ }^{\circ} \mathrm{C}$

\section{Influence of adsorbent concentration}

The adsorption experiments at initial chromium concentration $10 \mathrm{mg} / \mathrm{L}$ were also performed with MPGP doses (1,2,4,6 g/L) and FMPGP doses (1,4,8,12 g/L) at Cr(VI) conc. 10 and $40 \mathrm{mg} / \mathrm{L}$, the 
results are reported in Figure 4. Removal of $\mathrm{Cr}(\mathrm{VI})$ increases with an increase in the adsorbent. Dosage.

The percentage removal increases from 50.85 to $78.83 \%$ by increasing MPGP dosage from 1 to $6 \mathrm{~g} / \mathrm{L}$. while it increases from 70.67 to $80.82 \%$ at $\mathrm{Cr}(\mathrm{VI})$ conc. $10 \mathrm{mg} / \mathrm{L}$ and from 67.18 to 89.43 at $\mathrm{Cr}(\mathrm{VI})$ conc. $40 \mathrm{mg} / \mathrm{L}$ for FMPGP dosage increasing from 1 to $12 \mathrm{~g} / \mathrm{L}$. However, the adsorption capacity $\mathrm{q}_{\mathrm{e}}$ showed a decreasing trend with increasing adsorbent dosage. If the adsorbent amount is increased by keeping the $\mathrm{Cr}(\mathrm{VI})$ concentration constant, the amount of $\mathrm{Cr}(\mathrm{VI})$ adsorbed per unit mass showed a decrease due to availability of less number of $\mathrm{Cr}(\mathrm{VI})$ ions per unit mass of the adsorbent. The adsorption capacity dropped from 5.085 to $1.314 \mathrm{mg} / \mathrm{g}$ by increasing adsorbent dosage from 1 to $6 \mathrm{~g} / \mathrm{L}$ for MPGP, while, for FMPGP the $\mathrm{q}_{\mathrm{e}}$ dropped from 2.733 to 1.918 at $10 \mathrm{mg} / \mathrm{L}$ and from 26.873 to 2.981 at $40 \mathrm{mg} / \mathrm{L} \mathrm{Cr}(\mathrm{VI})$ concentration. The drop in adsorption capacity is basically due to the site remaining unsaturated during the adsorption process. The same trend was also reported by other researchers ${ }^{16}$.

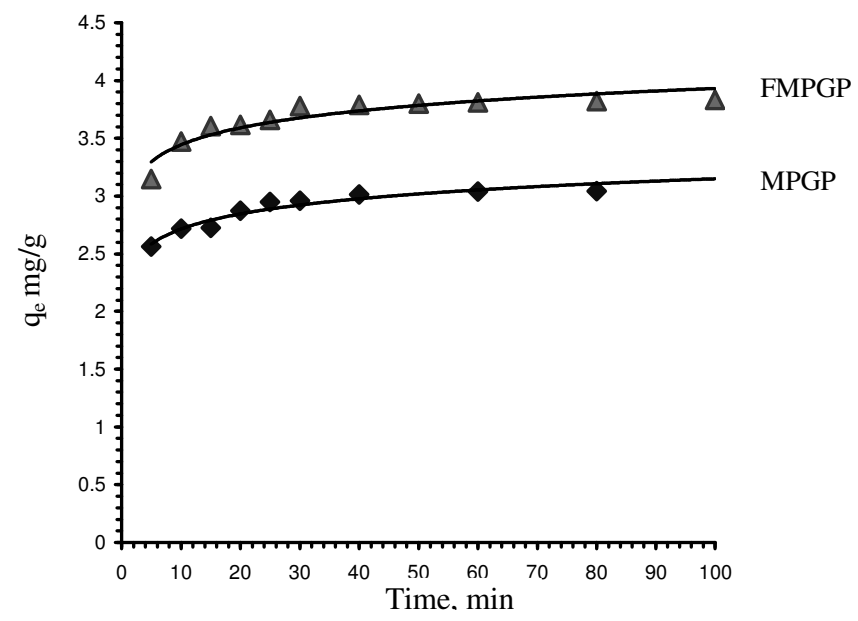

Figure 3. Effect of contact time on the amount of $\mathrm{Cr}(\mathrm{VI})$ adsorbed at equilibrium, $\mathrm{q}_{\mathrm{e}}$, using MPGP, $0.1 \mathrm{~g} / 50 \mathrm{~mL}$, at $\mathrm{pH} 2$, temp. $20^{\circ} \mathrm{C}$ and FMPGP, $0.1 \mathrm{~g} / 50 \mathrm{~mL}$, at $\mathrm{pH} 3$ temp. $16{ }^{\circ} \mathrm{C}$.

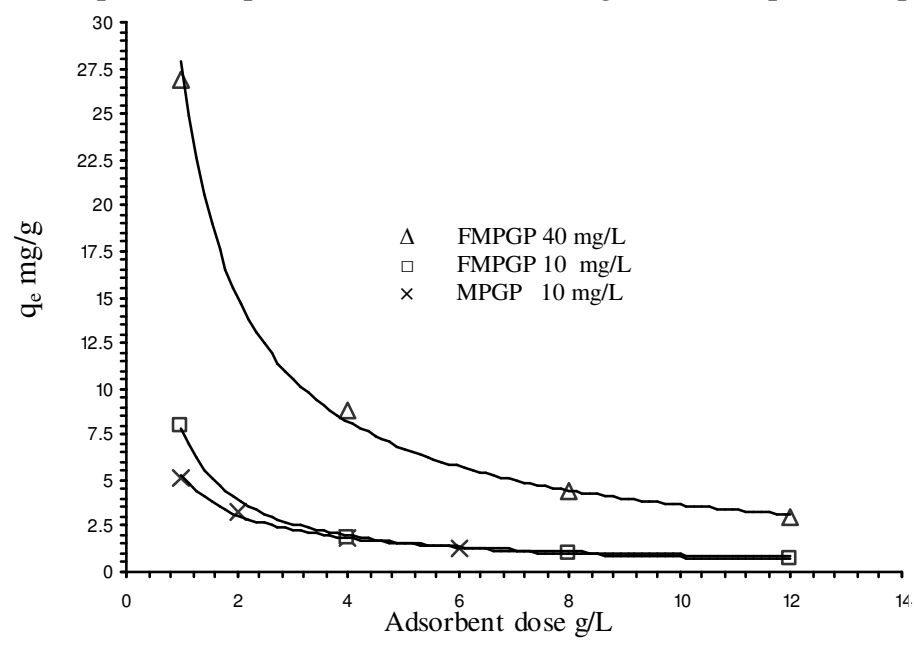

Figure 4. Effect of MPGP and FMPGP dosage on $\mathrm{Cr}(\mathrm{VI})$ adsorption. 


\section{Adsorption isotherm investigation}

Equilibrium data, commonly known as adsorption isotherm, are basic requirements for adsorption systems. The experimental data were fitted to the Langmuir, Freundlich, Temkin and Dubinin-Radushkevich (D-R) isotherm equations and the constant parameters of the isotherm equations were evaluated. For each isotherm, the temperature of solution and $\mathrm{Cr}(\mathrm{VI})$ concentration were varied while the adsorbent weight in each sample were held constant.

The Langmuir equation which is valid for monolayer adsorption onto a completely homogenous surface with finite number of identical sites and with negligible interaction between adsorbed molecules is represented in the following linear forms ${ }^{24}$ :

$$
\begin{aligned}
\frac{C_{e}}{q_{e}} & =\frac{1}{K_{L} Q_{m}}+\frac{C_{e}}{Q_{m}} \\
\text { or } \frac{1}{q_{e}} & =\left(\frac{1}{K_{L} Q_{m}}\right) \frac{1}{C_{e}}+\frac{1}{Q_{m}}
\end{aligned}
$$

$\mathrm{C}_{\mathrm{e}}$ is the equilibrium concentration in solution $(\mathrm{mg} / \mathrm{L}), \mathrm{q}_{\mathrm{e}}$ the amount of metal ion adsorbed $(\mathrm{mg} / \mathrm{L}), \mathrm{Q}_{\mathrm{m}}$ is the maximum monolayer capacity of the adsorbent $(\mathrm{mg} / \mathrm{g})$ and $\mathrm{K}_{\mathrm{L}}$ is an adsorption equilibrium constant $\left(\mathrm{Lmg}^{-1}\right)$ that related to the apparent energy of sorption. Equation (3) and (4) are the more popular linear forms of Langmuir isotherm. The values of $\mathrm{Q}_{\mathrm{m}}$ and $\mathrm{K}_{\mathrm{L}}$ constants and correlation coefficients for Langmuir isotherm were evaluated from a plot of $1 / \mathrm{q}_{\mathrm{e}}$ versus $1 / \mathrm{C}_{\mathrm{e}}$ Figure 5 and presented in Table 1, for MPGP and Table 2, for FMPGP adsorbent. Values of $\mathrm{Q}_{\mathrm{m}}$ for the adsorption of $\mathrm{Cr}(\mathrm{VI})$ onto MPGP increases with temperature increase, confirming that the process is endothermic for both adsorbents ${ }^{25}$. Although the correlation coefficients for the adsorption of $\mathrm{Cr}(\mathrm{VI})$ onto MPGP and FMPGP are high $>0.99$, but the theoretical values of $\mathrm{Q}_{\mathrm{m}}$ do not agree with the experimental values and they are higher than expected which indicate that the Langmuir model is not applicable.



Figure 5. Langmuir isotherm for the adsorption of $\mathrm{Cr}(\mathrm{VI})$ onto MPGP at different temperatures $(\mathrm{PH} 2$, contact time $=80 \mathrm{~min}$., MPGP dose $=2 \mathrm{~g} / \mathrm{L}$ ).

\section{The Freundlich isotherm}

The Freundlich isotherm is derived by assuming a heterogeneous surface with a non-uniform distribution of heat of sorption over the surface. It can be expressed in the linear form as follows ${ }^{26}$ : 


$$
\log q_{e}=\log K_{F}+\frac{1}{n} \log C_{e}
$$

where $\mathrm{K}_{\mathrm{F}}\left(\mathrm{Lmg}^{-1}\right)$ and $\mathrm{n}$ are isotherm constants indicate the capacity and intensity of the adsorption, respectively. The linear plot of $\log \mathrm{q}_{\mathrm{e}}$ versus $\log \mathrm{C}_{\mathrm{e}}$ at each temperature indicates that the adsorption of $\mathrm{Cr}(\mathrm{VI})$ also follow Frendlich isotherm Figures $6 \& 7$. Table $1 \& 2$ show the Frendlich isotherm constants and correlation coefficients for the adsorption of $\mathrm{Cr}(\mathrm{VI})$ on to MPGP and FMPGP adsorbents. The values of $n$ were greater than one indicating that the adsorption onto FMPGP and MPGP is favourable physical process except at $50{ }^{\circ} \mathrm{C}$ for MPGP, where its value is less than one indicating the adsorption mav he chemical ${ }^{27}$.



Figure 6. Freundlich isotherm for the adsorption of $\mathrm{Cr}(\mathrm{VI})$ onto MPGP at different temperature.

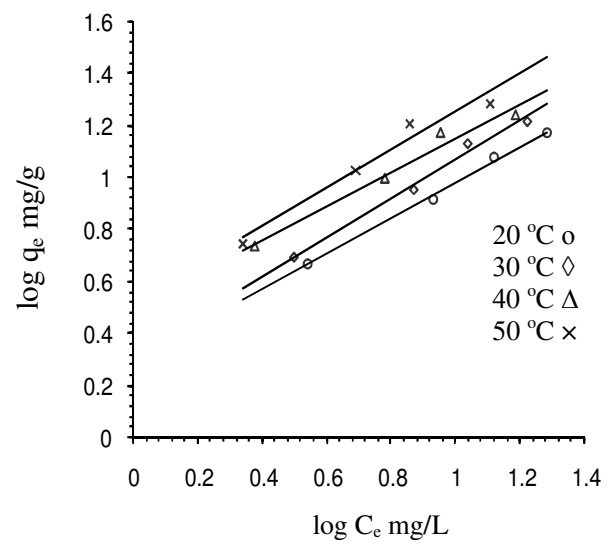

Figure 7. Freundlich isotherm for the adsorption of $\mathrm{Cr}(\mathrm{VI})$ onto FMPGP at different temperature.

Table 1. Comparison of the coefficients isotherm parameters from chromium (10, 20, 30, $40 \mathrm{mg} / \mathrm{L}$ ) adsorption onto MPGP .

\begin{tabular}{clcccc}
\hline \multirow{2}{*}{$\begin{array}{c}\text { Isotherm } \\
\text { model }\end{array}$} & \multirow{2}{*}{$\begin{array}{l}\text { Isotherm } \\
\text { parameter }\end{array}$} & \multicolumn{4}{c}{ Temperature $\mathrm{C}^{\mathrm{o}}$} \\
\cline { 3 - 6 } & & 20 & 30 & 40 & 50 \\
\hline \multirow{3}{*}{ Longmuir } & $\mathrm{Q}_{\mathrm{m}}, \mathrm{mg}^{\prime} \mathrm{g}$ & 20.921 & 26.882 & 47.39 & 47.17 \\
& $\mathrm{~K}_{\mathrm{L}} \mathrm{L} \mathrm{mg}^{-1}$ & 0.054 & 0.042 & 0.023 & 0.017 \\
& $\mathrm{R}^{2}$ & 0.9974 & 0.9997 & 0.9994 & 0.9758 \\
\hline \multirow{5}{*}{ Freundlich } & $\mathrm{K}_{\mathrm{F}}$ & 1.514 & 1.377 & 1.262 & 0.9078 \\
& $\mathrm{n}$ & 1.506 & 1.339 & 1.183 & 1.979 \\
& $\mathrm{R}^{2}$ & 0.9741 & 0.9957 & 0.9974 & 0.9506 \\
\hline \multirow{5}{*}{ Tempkin } & $\mathrm{A}_{\mathrm{T}}$ & 0.434 & 0.576 & 0.665 & 0.863 \\
& $\mathrm{~B}_{\mathrm{T}}$ & 4.02 & 4.789 & 5.742 & 7.002 \\
& $\mathrm{~b}_{\mathrm{T}}$ & 606 & 525.99 & 453.19 & 383.5 \\
& $\mathrm{R}^{2}$ & 0.9955 & 0.9876 & 0.9817 & 0.9827 \\
\hline \multirow{5}{*}{$\mathrm{D}-\mathrm{R}$} & $\mathrm{Q}_{\mathrm{m}} \mathrm{mg} / \mathrm{g}$ & 9.4669 & 10.133 & 11.182 & 13.0085 \\
& $\mathrm{~K}_{\mathrm{D}-\mathrm{R}} \mathrm{X} \mathrm{10}$ & 3 & 3 & 3.0 & 4 \\
& $\mathrm{E}^{6}, \mathrm{kJmol}^{-1}$ & 0.00173 & 0.00173 & 0.00173 & 0.002 \\
& $\mathrm{R}^{2}$ & 0.9504 & 0.9276 & 0.9285 & 0.9727 \\
\hline
\end{tabular}


Table 2. Comparison of the coefficients isotherm parameters from chromium $(10,20,30,40$ mg/L) adsorption onto FMPGP .

\begin{tabular}{|c|c|c|c|c|c|}
\hline \multirow{2}{*}{$\begin{array}{c}\text { Isotherm } \\
\text { model }\end{array}$} & \multirow{2}{*}{$\begin{array}{l}\text { Isotherm } \\
\text { parameter }\end{array}$} & \multicolumn{4}{|c|}{ Temperature $\mathrm{C}^{\mathrm{O}}$} \\
\hline & & 20 & 30 & 40 & 50 \\
\hline \multirow{3}{*}{ Longmuir } & $\mathrm{Q}_{\mathrm{m},} \mathrm{mg} / \mathrm{g}$ & 25.38 & 35.336 & 30.395 & 49.75 \\
\hline & $\mathrm{K}_{\mathrm{L}}, \mathrm{L} \mathrm{mg}^{-1}$ & 0.0636 & 0.0507 & 0.0903 & 0.0577 \\
\hline & $\mathrm{R}^{2}$ & 0.9908 & 0.9926 & 0.9909 & 0.9917 \\
\hline \multirow{3}{*}{ Freundlich } & $\overline{K_{F}}$ & 1.953 & 2.074 & 3.136 & 3.299 \\
\hline & $\mathrm{n}$ & 1.452 & 1.333 & 1.524 & 1.361 \\
\hline & $\mathrm{R}^{2}$ & 0.9953 & 0.9882 & 0.9739 & 0.9619 \\
\hline \multirow{4}{*}{ Tempkin } & $A_{t}$ & 0.574 & 0.5844 & 0.887 & 0.881 \\
\hline & $\mathrm{B}_{\mathrm{t}}$ & 5.924 & 7.075 & 6.732 & 8.128 \\
\hline & $\mathrm{b}_{\mathrm{T}}$ & 411.21 & 356.06 & 386.55 & 330.39 \\
\hline & $\mathrm{R}^{2}$ & 0.9654 & 0.9654 & 0.9659 & 0.973 \\
\hline \multirow{4}{*}{ D-R } & $\mathrm{Q}_{\mathrm{m}}, \mathrm{mg} / \mathrm{g}$ & 16.928 & 19.595 & 20.156 & 22.28 \\
\hline & $K_{D-R} \times 10^{6}$ & 10 & 8 & 4 & 3 \\
\hline & $\mathrm{E}, \mathrm{kJmol}^{-1}$ & 0.0032 & 0.0028 & 0.002 & 0.0017 \\
\hline & $\mathrm{R}^{2}$ & 0.9946 & 0.9996 & 0.9905 & 0.9889 \\
\hline
\end{tabular}

\section{Temkin isotherm}

The adsorbing species-adsorbate interactions can be explained using the tempkin isotherm equation ${ }^{28}$. It is based on the following assumptions:

1. The heat of adsorption of all the molecules in the layer decreases linearly with coverage due to adsorbate-adsorbate repulsions.

2. The adsorption is a uniform distribution of maximum binding energy.

3. The fall in the heat of sorption is linear rather than logarithmic, as implied in the Freundlich equation. It is commonly expressed in the following linear equation.

$$
\begin{aligned}
q_{e} & =B_{T} \ln A_{T}+B_{T} \ln C_{e} \\
B_{T} & =\frac{R T}{b}
\end{aligned}
$$

where, $\mathrm{T}$ is the absolute temperature $(\mathrm{K})$, and $\mathrm{R}$ is the universal gas constant, $8.314 \mathrm{Jmol}^{-1} \mathrm{~K}^{-1}$. $\mathrm{b}(\mathrm{J} / \mathrm{mol})$ is a constant related to the heat of adsorption. $\mathrm{A}_{\mathrm{T}}$ is the equilibrium binding constant $\left(\mathrm{Lmg}^{-1}\right)$. A plot of $\mathrm{q}_{\mathrm{e}}$ versus $\operatorname{lnC}_{\mathrm{e}}$ at studied temperatures for adsorption of $\mathrm{Cr}(\mathrm{VI})$ onto MPGP is given in Figure 8, while, the Tempkin constants for both adsorbents are summarized in Table $1 \& 2$ respectively. The correlation coefficients was relatively high, which indicate the applicability of Temkin equation. The Tempkin constant, $\mathrm{B}_{\mathrm{T}}$, for the adsorption of $\mathrm{Cr}(\mathrm{VI})$ onto MPGP and FMPGP show that the heat of adsorption increases with temperature increase indicating endothermic process.

\section{The Dubinin-Radushkevich isotherm}

The linear form of D-R isotherm equation can be expressed as follows ${ }^{29}$.

$$
\ln q_{e}=\ln Q_{m}-K_{D-R} \varepsilon^{2}
$$

where $\mathrm{Q}_{\mathrm{m}}$ is the theoretical monolayer saturation capacity $\left(\mathrm{mg} \mathrm{g}^{-1}\right)$,

$\mathrm{K}_{\mathrm{D}-\mathrm{R}}$ is the D-R constant $\left(\mathrm{mol}^{2} \mathrm{KJ}^{-2}\right)$. $\varepsilon$, is the Polanyi potential and is equal to the mean energy of adsorption, $\mathrm{E}\left(\mathrm{kJmol}^{-1}\right)$ is related to $\mathrm{K}_{\mathrm{D}-\mathrm{R}} \mathrm{as}^{30}$ :

$$
\varepsilon=R T \ln \left[1+\frac{1}{C_{e}}\right]
$$




$$
E=\frac{1}{\sqrt{2 K_{D-R}}}
$$

The coefficients of D-R isotherm for adsorption onto MPGP and FMPGP adsorbents are presented in Table $1 \& 2$ respectively. Plot of $\ln \mathrm{q}_{\mathrm{e}} v s . \varepsilon^{2}$ for the adsorption of $\mathrm{Cr}(\mathrm{VI})$ onto MPGP are shown in Figure 9. The values of the mean adsorption energy (E) were found to be in the range of physical adsorption ${ }^{25}$ Table $1 \& 2$. The $\mathrm{Q}_{\mathrm{m}}$ values were found to be increased with increase in temperature, this behavior is an indication of endothermic adsorption process Table $1 \& 2$. Although, the correlation coefficients of D-R isotherm for adsorption onto MPGP and FMPGP Table $1 \& 2$, are little bit lower than that of Langmuir isotherm, but theoretical values of $\mathrm{Q}_{\mathrm{m}}$ are much closer to experimental values and even closer than that values obtained from Langmuir isotherm . We suggest that D-R isotherm is more applicable for the adsorption of $\mathrm{Cr}(\mathrm{VI})$ onto MPGP and FMPGP Table $1 \& 2$.

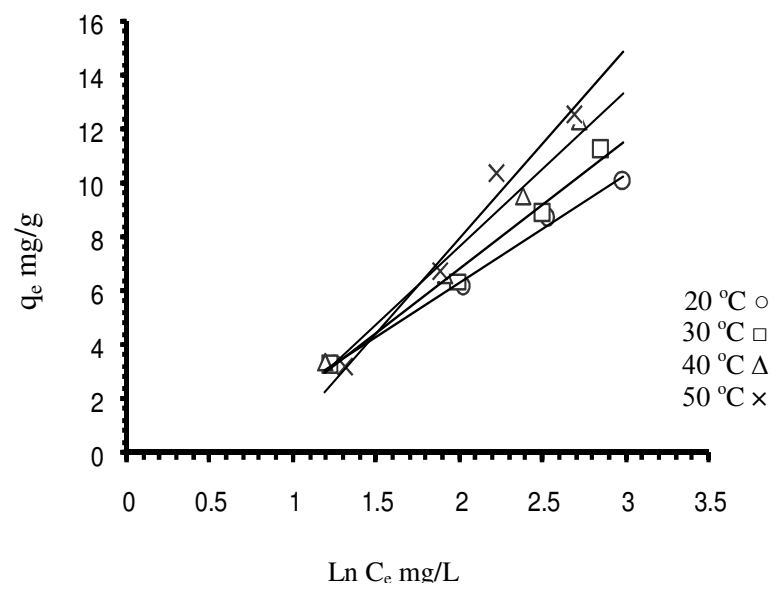

Figure 8. Temkin isotherm for the adsorption of MPGP at different temperatures.



Figure 9. D-R isotherm for the adsorption of $\mathrm{Cr}(\mathrm{VI})$ onto MPGP. 


\section{Adsorption kinetic study}

The dynamics of the adsorption reaction in terms of the order of the rate constant can be understood by studying the kinetic of the adsorption. Batch experiments were conducted to study the rate of $\operatorname{Cr}(10 \mathrm{mg} / \mathrm{L})$ adsorption by MPGP and FMPGP. Several models were studied to examine the rate- controlling steps of the adsorption process such as chemical reaction, diffusion control and mass transfer. The pseudo-first $\operatorname{order}^{31}$, pseudo-second $\operatorname{order}^{32}$, Elovich ${ }^{33}$, and intraparticle diffusion ${ }^{34}$ kinetic models were used for the adsorption of $\mathrm{Cr}(\mathrm{VI})$ on MPGP and FMPGP.

\section{Pseudo-first order model}

The linear form of pseudo- first order kinetic model as follows ${ }^{31}$.

$$
\log \left(q_{e}-q_{t}\right)=\log q_{e}-\frac{k}{2.303} t
$$

where $\mathrm{q}_{\mathrm{e}}$ and $\mathrm{q}_{\mathrm{t}}$ are the amount of $\mathrm{Cr}$ adsorbed $\left(\mathrm{mg} \mathrm{g}^{-1}\right)$ at equilibrium and at any time $\mathrm{t}$, respectively, and $\mathrm{k}_{1}\left(\mathrm{~min}^{-1}\right)$ is the equilibrium rate constant of pseudo-first order adsorption. From plot of $\log \left(\mathrm{q}_{\mathrm{e}}-\mathrm{q}_{\mathrm{t}}\right)$ vs. $\mathrm{t}$, the rate constant $\mathrm{k}_{1}$, equilibrium adsorption capacity, $\mathrm{q}_{\mathrm{e}}$, and correlation coefficient $\mathrm{R}^{2}$ were calculated. The first-order kinetic model for the adsorption of $\mathrm{Cr}(\mathrm{VI})$ onto both MPGP and FMPGP is not applicable due to the low correlation coefficient values and big difference between experimental and calculated values of $\mathrm{q}_{\mathrm{e}}$ Tables $3 \& 4$.

\section{Pseudo-second-order equation}

The second-order kinetic equation can be represented as follows ${ }^{32}$.

$$
t / q_{t}=\frac{1}{k_{2} q_{e}{ }^{2}}+\frac{1}{q_{e}}(t)
$$

Where $\mathrm{k}_{2}\left(\mathrm{~g} \mathrm{mg}^{-1} \mathrm{~min}^{-1}\right)$ is the equilibrium rate constant of pseudo-second-order adsorption. The initial adsorption rate, $\mathrm{h}\left(\mathrm{mg} \mathrm{g}^{-1} \mathrm{~min}^{-1}\right)$ is expressed by the following equation:

$$
h=k_{2} q_{e}^{2}
$$

The linear plot of $t / \mathrm{q}_{\mathrm{t}} v s . \mathrm{t}$ shows a good agreement for the experimental data with the pseudo-second-order kinetic model for adsorption of Cr onto MPGP and FMPGP. The correlation coefficients $\left(\mathrm{R}^{2}\right)$ are higher than 0.9989 . The calculated $\mathrm{q}_{\mathrm{e}}$ values agree very well with experimental data (Tables $3 \& 4$, Figures $10 \& 11$ ). These suggest that the adsorption of $\mathrm{Cr}$ from aqueous solution onto MPGP and FMPGP follow the pseudo-second order model. It is observed that the initial adsorption rate, $h$ is higher for the adsorption of $\mathrm{Cr}(\mathrm{VI})$ onto FMPGP than onto MPGP Tables 3 \& 4. This behavior was obvious in Figure 3.

The equilibrium between $\mathrm{Cr}(\mathrm{VI})$ in solution and that onto MPGP or FMPGP can be represented as follows:

$$
\mathrm{C}_{\mathrm{e}} \underset{\mathrm{k}-1}{\stackrel{\mathrm{k}_{1}}{<}} \mathrm{C}_{\mathrm{a}}
$$

Where $\mathrm{k}_{1}$ and $\mathrm{k}_{-1}$ are the forward (adsorption) and reverse (desorption) rate constants respectively. $\mathrm{C}_{\mathrm{e}}$ and $\mathrm{C}_{\mathrm{a}}$ are $\mathrm{Cr}(\mathrm{VI})$ ion concentration in solution and onto adsorbent respectively. The equilibrium constant $\left(\mathrm{K}_{\mathrm{o}}\right)$ is the ratio of $\mathrm{Cr}(\mathrm{VI})$ concentration on the MPGP and in aqueous solution $\left(\mathrm{K}_{\mathrm{o}}=\mathrm{C}_{\mathrm{a}} / \mathrm{C}_{\mathrm{e}}=\mathrm{k}_{1} / \mathrm{k}_{-1}\right)$. The second order rate constant $\left(\mathrm{k}_{2}\right)$ have been calculated from the linear plots of $\mathrm{t} / \mathrm{q}_{\mathrm{t}} v s$. $\mathrm{t}$ at different time intervals and temperatures Table 3, Figure 10. 


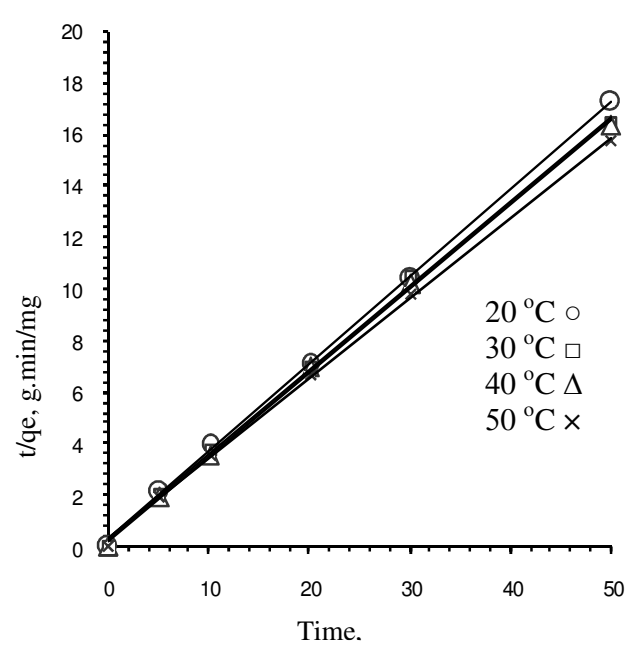

Figure 10. Pseudo-second-order kinetics for the adsorption of $\mathrm{Cr}(\mathrm{VI}) 10 \mathrm{mg} / \mathrm{L}$ onto MPGP MPGP 2 g/L, $\mathrm{pH} 2$.

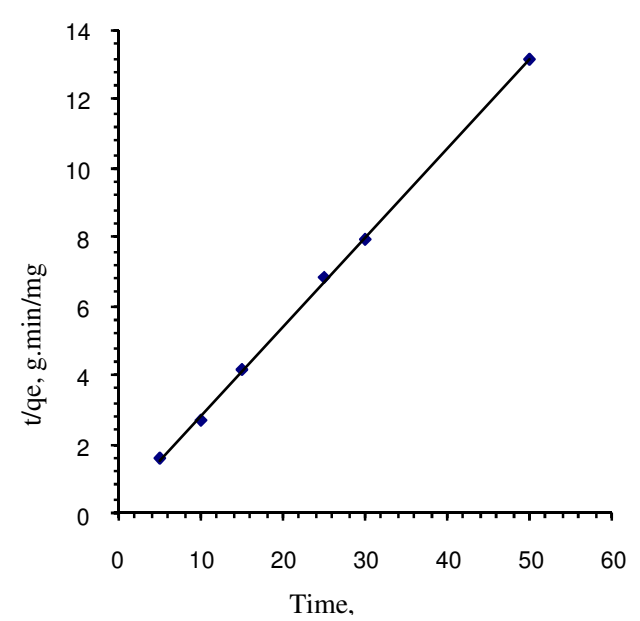

Figure 11.Pseudo-second-order kinetics for the adsorption of $\mathrm{Cr}(\mathrm{VI}), 10 \mathrm{mg} / \mathrm{L}$, onto FMPGP. FMPGP $2 \mathrm{~g} / \mathrm{L}, \mathrm{pH} 3$ at $16^{\circ} \mathrm{C}$.

The overall rate of adsorption $\left(\mathrm{k}_{2}\right)$ is separated into the rate of forward and reverse reaction as follows:

$$
k_{2}=k_{1}+k_{-1}=k_{1}+\left(\frac{k_{1}}{K_{0}}\right)=k_{1}\left[1+\frac{1}{K_{0}}\right]
$$

These results are collected in Table 5, which indicate that at $10 \mathrm{mg} / \mathrm{L} \mathrm{Cr}(\mathrm{VI})$ concentration and all temperatures studied, the forward rate constants are much higher than the reverse rate constants suggesting that the rate of adsorption is clearly dominant ${ }^{35}$.

\section{Elovich kinetic equation}

Elovich equation is another kinetic model with a linear form can be expressed as follows ${ }^{33}$ :

$$
q_{t}=\frac{1}{\beta} \ln (\alpha \beta)+\frac{1}{\beta} \ln (t)
$$

Elovich constants $\alpha$ and $\beta$ were calculated from slope and intercept of plot of $\mathrm{q}_{\mathrm{t}} v s \cdot \ln (\mathrm{t})$. The correlation coefficients is some what high $R^{2}>0.92$ which reflected the applicability of the Elovich model.



Figure 12. Elovich kinetic for the adsorption of $\mathrm{Cr}(\mathrm{VI})$ onto MPGP. 
Table 3. Comparison of the first order, second order, Elovich and intraparticle diffusion rate constants and calculated and experimental $\mathrm{q}_{\mathrm{e}}$ values at different temperature and different time intervals at constant concentration of $\mathrm{Cr}(\mathrm{VI}) 10 \mathrm{mg} / \mathrm{L}$ and constant dose of MPGP $2 \mathrm{~g} / \mathrm{L}$.

\begin{tabular}{|c|c|c|c|c|c|c|c|c|c|c|c|c|c|c|}
\hline \multicolumn{2}{|c|}{ Parameter } & \multicolumn{3}{|c|}{ First-order kinetic model } & \multicolumn{4}{|c|}{ Second- order kinetic model } & \multicolumn{3}{|c|}{ Elovich } & \multicolumn{3}{|c|}{ Intraparticle diffusion } \\
\hline $\begin{array}{c}\text { Temp } \\
\text { C }^{\mathrm{O}}\end{array}$ & $\begin{array}{c}\mathrm{q}_{\mathrm{e}} \\
(\exp )\end{array}$ & $\begin{array}{l}\mathrm{k}_{1} \\
10^{2}\end{array}$ & $\begin{array}{c}\mathrm{q}_{\mathrm{e}} \\
\text { (calc.) }\end{array}$ & $\mathrm{R}^{2}$ & $\begin{array}{c}\mathrm{k}_{2} \\
10^{2}\end{array}$ & $\begin{array}{c}\mathrm{q}_{\mathrm{e}} \\
\text { (calc.) }\end{array}$ & $\mathrm{mg} \mathrm{g}^{-1} \min ^{-1}$ & $\mathrm{R}^{2}$ & $\alpha$ & $\beta$ & $\mathrm{R}^{2}$ & $\begin{array}{l}\text { Kdiff } \\
\times 10^{2}\end{array}$ & $\mathrm{~B}_{\mathrm{L}}$ & $\mathrm{R}^{2}$ \\
\hline 20 & 2.937 & 6.0 & 0.589 & 0.852 & 23.3 & 2.989 & 2.082 & 0.9997 & 326.587 & 3.694 & 0.9214 & 12.15 & 2.146 & 0.8161 \\
\hline 30 & 3.059 & 7.9 & 1.077 & 0.9197 & 32.0 & 3.124 & 3.123 & 0.9989 & 672.134 & 3.873 & 0.9685 & 11.99 & 2.2227 & 0.9183 \\
\hline 40 & 3.172 & 3.25 & 0.598 & 0.9684 & 24.6 & 3.111 & 2.381 & 0.9995 & 46424.43 & 5.356 & 0.9637 & 8.7 & 2.46 & 0.9209 \\
\hline 50 & 3.385 & 2.79 & 0.774 & 0.9597 & 19.7 & 3.259 & 2.092 & 0.9997 & 2663.31 & 4.142 & 0.9914 & 11.01 & 2.431 & 0.9399 \\
\hline
\end{tabular}

Table 4. Comparison of the first order, second order, Elovich and intraparticle diffusion rate constants and calculated and experimental $\mathrm{q}_{\mathrm{e}}$ values for the adsorption of $\mathrm{Cr}(\mathrm{VI}), 10 \mathrm{mg} / \mathrm{L}$, onto FMPGP, $2 \mathrm{~g} / \mathrm{L}$, at constant temperature $16{ }^{\circ} \mathrm{C}$ and different time intervals .

\begin{tabular}{|c|c|c|c|c|c|c|c|}
\hline \multicolumn{4}{|c|}{ first order kinetic model } & \multicolumn{4}{|c|}{ Second order kinetic model } \\
\hline $\mathrm{q}_{\mathrm{e}}($ exp. $), \mathrm{mg} / \mathrm{g}$ & $\mathrm{k}_{1,} \min ^{-1}$ & $\mathrm{q}_{\mathrm{e}}($ calc. $) \mathrm{mg} / \mathrm{g}$ & $\mathrm{R}^{2}$ & $\mathrm{k}_{2}, \mathrm{~g} \mathrm{mg}^{-1} \mathrm{~min}^{-1}$ & $\mathrm{~h}, \mathrm{mgg}^{-1} \min ^{-1}$ & $\mathrm{q}_{\mathrm{e}}$ (calc.) & $\mathrm{R}^{2}$ \\
\hline 3.823 & 0.076 & 0.762 & 0.8878 & 0.277 & 4.142 & 3.867 & 0.9995 \\
\hline \multicolumn{4}{|c|}{ Elovich model } & \multicolumn{4}{|c|}{ intraparticle diffusion } \\
\hline \multicolumn{2}{|c|}{$\mathrm{B}, \mathrm{g} \mathrm{mg}^{-1}$} & $\mathrm{~A}, \mathrm{mg} \mathrm{g}^{-1} \min ^{-1}$ & $\mathrm{R}^{2}$ & \multicolumn{2}{|c|}{$\mathrm{K}_{\text {diff., }} \mathrm{mg} \mathrm{g}^{-1} \min ^{-1 / 2}$} & $\mathrm{~B}_{\mathrm{L},} \mathrm{mg} / \mathrm{g}$ & $\mathrm{R}^{2}$ \\
\hline \multicolumn{2}{|c|}{0.361} & 7.54 & 0.9249 & \multicolumn{2}{|c|}{0.126} & 3.015 & 0.8186 \\
\hline
\end{tabular}

Table 5. Second order rate constants for the adsorption of chromium onto MPGP $\left(\mathrm{k}_{2}, \mathrm{qmg}^{-1} \mathrm{~min}^{-1}\right)$ Equilibrium constant $\left(\mathrm{K}_{0}\right)$, rate constants for forward $\left(\mathrm{k}_{1}\right)$ and reverse $\left(\mathrm{k}_{-1}\right)$ process at different temperatures .

\begin{tabular}{cccccc}
\hline $\begin{array}{c}\text { Temperature } \\
\mathrm{C}^{\mathrm{o}}\end{array}$ & $\mathrm{C}_{\mathrm{e}}, \mathrm{mg} / \mathrm{L}$ & $\mathrm{K}_{0}$ & $\begin{array}{c}\mathrm{k}_{2}, \\
\mathrm{~g} \mathrm{mg}^{-1} \mathrm{~min}^{-1}\end{array}$ & $\begin{array}{c}\mathrm{k}_{1}, \\
\mathrm{~g} \mathrm{mg}^{-1} \min ^{-1}\end{array}$ & $\begin{array}{c}\mathrm{k}_{-1,} \\
\mathrm{~g} \mathrm{mg}^{-1} \min ^{-1}\end{array}$ \\
\hline 20 & 4.127 & 1.423 & 0.233 & 0.1368 & 0.0962 \\
30 & 3.883 & 1.575 & 0.320 & 0.1425 & 0.0905 \\
40 & 3.657 & 1.734 & 0.246 & 0.1477 & 0.0852 \\
50 & 3.231 & 2.095 & 0.197 & 0.1577 & 0.0753 \\
\hline
\end{tabular}




\section{Intraparticle diffusion}

The adsorption mechanism of adsorbent follows three steps viz. film diffusion, pore diffusion and intra-particle transport. The slowest of the three steps controls the overall rate of the process. Generally, pore diffusion and intra-particle diffusion are often rate-limiting in a batch reactor, which for continuous flow system film diffusion is more likely the rate limiting step ${ }^{36}$.

The linear form of intra-particle diffusion model can be expressed as follows ${ }^{34}$.

$$
q_{t}=K_{\text {dif }} t^{1 / 2}+B_{L}
$$

where $\mathrm{K}_{\text {dif }}\left(\mathrm{mg} \mathrm{g}^{-1} \mathrm{~min}^{-1 / 2}\right)$ is the intraparticle diffusion rate constant. In Figure 13 a plot of $\mathrm{q}_{\mathrm{t}}$ versus $\mathrm{t}^{1 / 2}$ are presented for MPGP. Values of $\mathrm{B}_{\mathrm{L}}$ give an idea about the thickness of the boundary layer ${ }^{37}$, which is higher in FMPGP Tables $3 \& 4$.

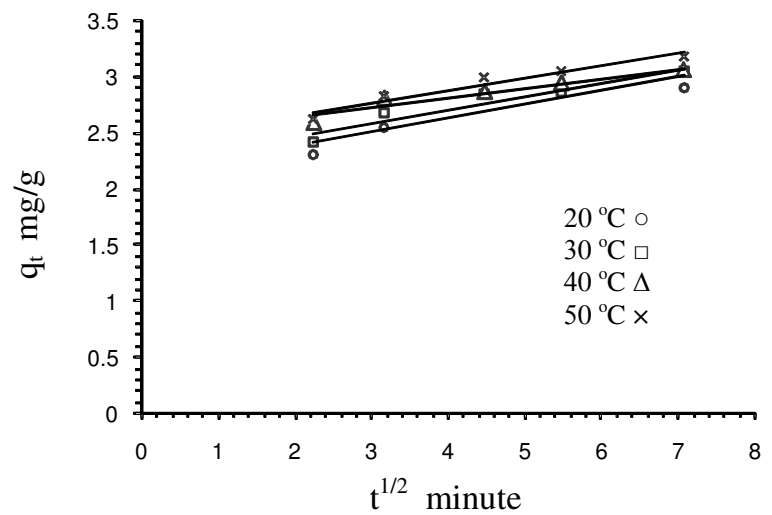

Figure 13. Intraparticle diffusion plot for $\mathrm{Cr}(\mathrm{VI}) 10 \mathrm{mg} / \mathrm{L}$ adsorption onto MPGP $2 \mathrm{~g} / \mathrm{L}, \mathrm{pH}$ 2 at different time and temperature.

The correlation coefficients of the plot range between 0.8161-0.9399 which indicate low linearity for the adsorption of $\mathrm{Cr}(\mathrm{VI})$ by MPGP or FMPGP. Moreover, it has been reported 38,39 that if intraparticle diffusion is the sole rate-limiting step, it is for the $\mathrm{q}_{\mathrm{t}}$ versus $\mathrm{t}_{1 / 2}$ plots to pass through the origin, which is not the case in this study. It may be concluded that surface adsorption and intraparticle diffusion were concurrently operating during the chromium-absorbent interactions. The evidence for such conclusion is the rate constants of second-order and intraparticle diffusion, where their values are the highest among other kinetic models, Table $3 \& 4$, large values of rate constants are related to an improved bonding between $\mathrm{Cr}(\mathrm{VI})$ ions and adsorbent particles ${ }^{40}$.

\section{References}

1. Karthikeyan M T, Rajgopal S and Miranda L R, J Hazard Mater., 2005,124(1-3),192-199.

2. Gao H, Liu Y, Zeng G, Xu W, Li T and Xia W, J Hazard Mater., 2007, 150(2), 446-452 .

3. Raji C and Anirudhan T S, Water Res., 1998, 32, 3772-3780.

4. Pellerin C and Bookey S M, Environ Health Perspect., 2000 ,108(9), 402-407.

5. Gode F and Pehlivan E, J Hazard Mater., 2005, B119, 175-182.

6. Ko Y G, choi U S, Kim T Y, Ahn D J and Chun Y J, Macromol Rapid Commun., 2002, 23, 535-539.

7. Richard F C and Bourg A C M, Water Res., 1991, 25(7), 807-816.

8. Ramos R L, Martinez A J and Coronado R M G, Water Sci Technol., 1994, 30(9), 191-197.

9. Rich G and Cherry K, Hazardons Waste Treatment Technology, Pudvan Publ. Co., New York, 1987. 
10. Volesky B, Biosorption of Heavy Metals, CRC press, Boston, USA, 1990.

11. Aksu Z, Gönen F and Demircan Z, Process Biochem., 2002, 38, 175.

12. Babel S and Kumiawan T A, J Hazard Mater., 2003, B97, 219.

13. Baran A, Bicak, Baysal S H and Onal S, Bioresour Technol., 2006, 98, 661.

14. El-Sikaily A, El Nemr A, Khaled A and Abdelwahab O, J Hazard Mater., 2007, 148(1-2), 216.

15. El-Nemr A, El-Sikaily A, Khaled A and Abdelwahab O, Chem Ecology, 2007, 23(2), 119.

16. El-Nemr A, J Hazard Mater., 2009,161(1), 132-141.

17. Ansari R and Raofie F, E Journal of Chemistry, 2006, 3(10), 49-59.

18. Santhy K and Selvapathy P, Separation Science and Technology, 2004, 39(14), 3331-3351.

19. Najim T S, Elias N J and Dawood A A, E-Journal of Chemistry, 2009, 6(1), 161-168.

20. Al-Ashtoukhy ESZ, Amin N K and Abdelwahab O, Desalination, 2008, 223, 162-173.

21. (a) Saiful Azhar A, Ghaniey Liew A, Suhardy D, Farizul Hafiz K and Irfan M D, Am J Appl Sci.,2005, 2(11), 1499-1503; (b) Weckhuysen B M, Wachs I E and Schoonheydt R A, Chem Rev., 1996, 96, 3327.

22. Mor S, Ravindra K and Bishnoi N R, Bioresour Technol., 2007, 98, 954.

23. Selvi K, Pattabhi S and Kadirvelu K, Bioresour Technol., 2001, 80, 87.

24. Langmuir I, J Am Chem Soc., 1916, 38, 2221-2295.

25. Abdelwahab O, Desalination, 2008, 222, 357-367.

26. Freundlich H M F, Phys Chem., (Leipzig), 1906, 57A, 385- 470.

27. El Nemr A, Chem Ecology, 2007, 23(5), 409-425.

28. (a) Temkin M J and Pyzhev V, Acta Physiochim., URSS, 1940,12, 217-222; (b) Amin N K, J Hazard Mater., 2009, 165(1-3),52-62.

29. Dubinin M M and Radushkevich LV, Chem Zentr., 947, 1(1), 875.

30. Dubinin M M, Chem Rev., 1960, 60, 235-266.

31. Langergren S, Veternskapsakad Handlingar, 1898, 24, 1-39.

32. Ho Y S, Mackay G, Wase D A J and Foster C F, Adsorp Sci Technol., 2000,18, 639.

33. Chien S H and Clayton W R, Soil Sci Soc Am J, 1980, 44, 265-268.

34. Weber W J and Morris J C, J Sanit Eng Div., ASCE, 1963, 89(SA2), 31-59.

35. Arivoli S, Hema M, Karuppaiah M and Saravanan S, E Journal of Chemistry, 2008, 5(4), 820-831.

36. Coswami S and Ghosh U C, Water SA, 2005, 31, 597- 602.

37. Kannan K, and Sundaram M M, Dyes and Pigments, 2001, 51, 25-40.

38. Ho Y S, Water Res., 2003, 37, 2323- 2330.

39. Crini G, Peindy H N , Gimbert F and Robert C, Sep Putif Technol., 2007, 53, 97-110.

40. Demirbas E, Kobya M, Senturk E and Ozkan T, Water SA, 2004, 30(4), 533-540. 


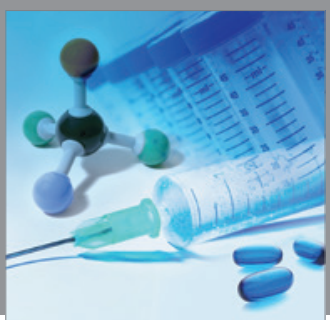

International Journal of

Medicinal Chemistry



Carbohydrate Chemistry



The Scientific World Journal
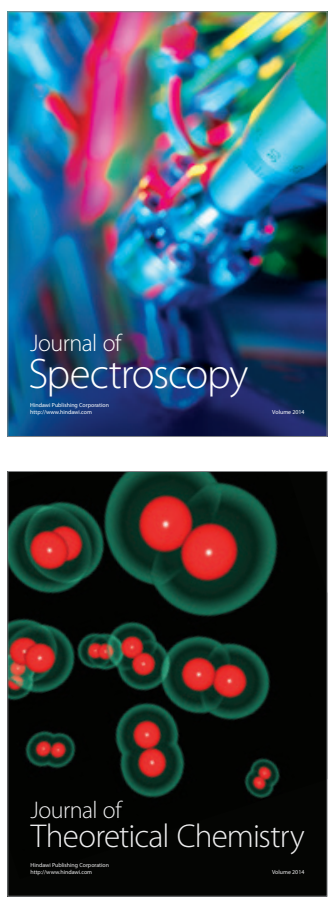
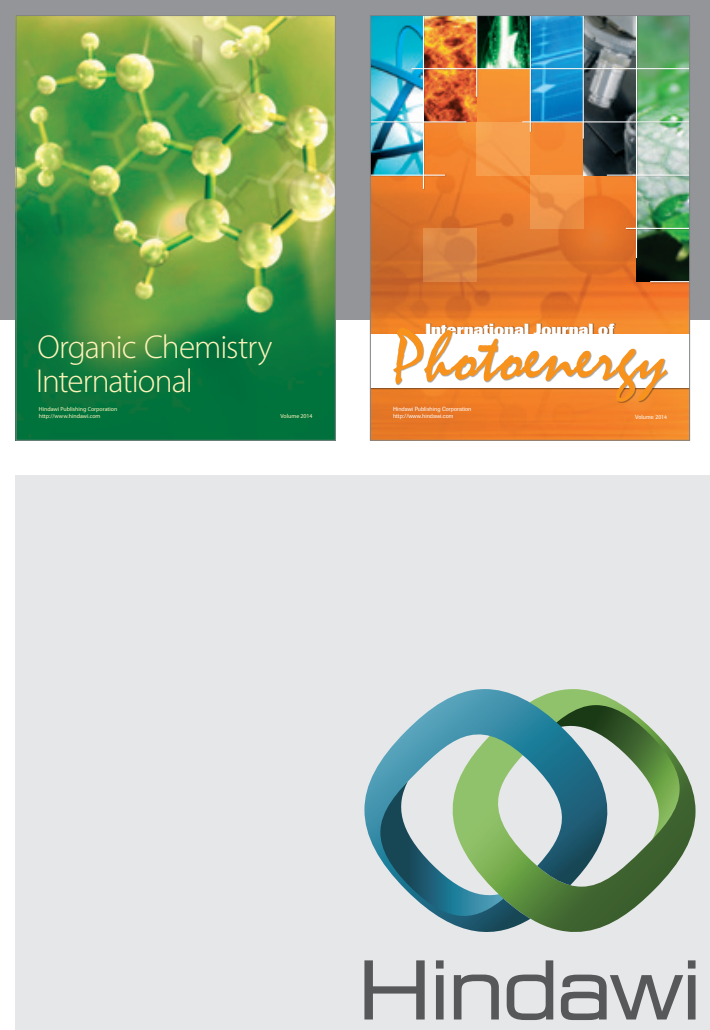

Submit your manuscripts at

http://www.hindawi.com
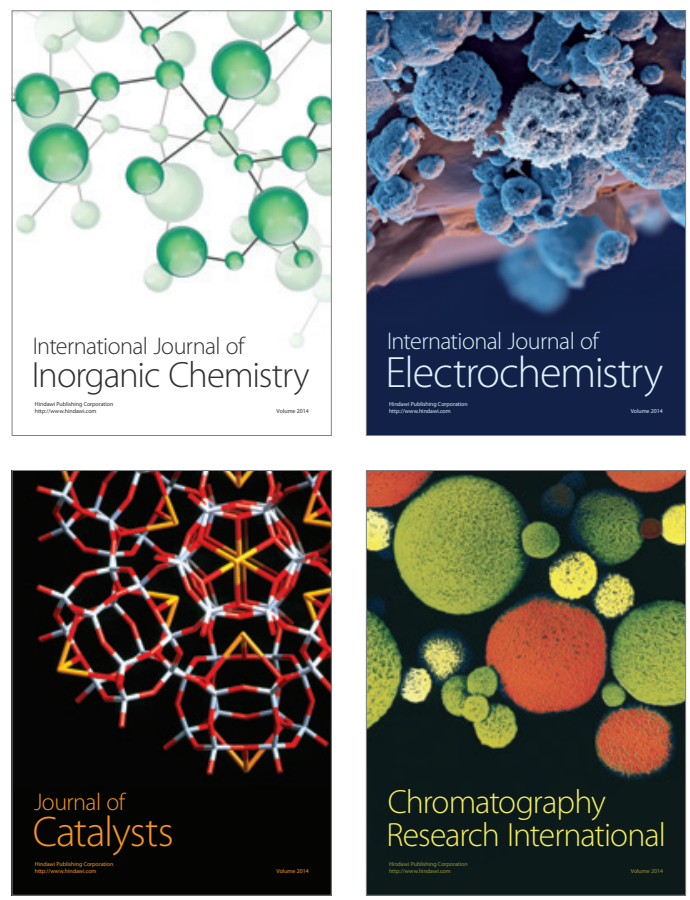
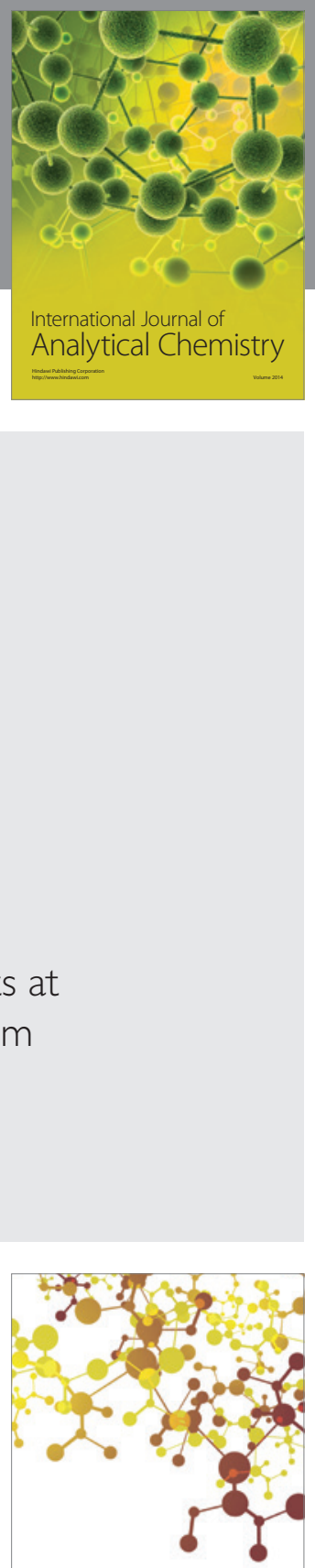

Journal of

Applied Chemistry
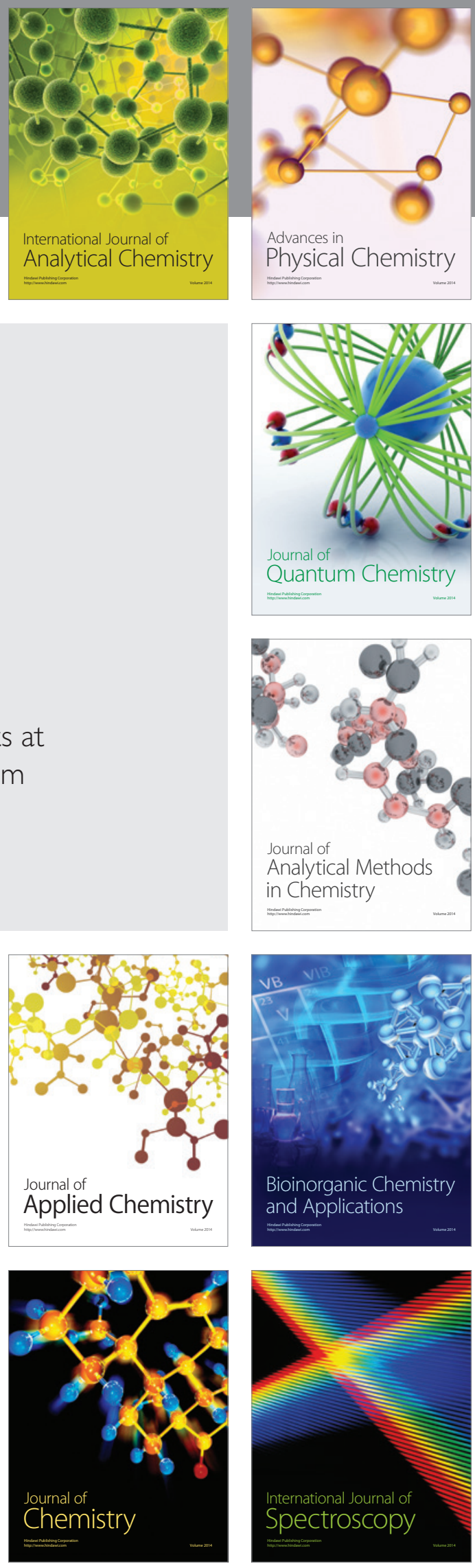